\title{
Hubungan Coping Stress Dengan Motivasi Belajar Mahasiswa Prodi BK pada Mata Kuliah Statistika
}

\author{
Nurul Azmi Saragih, Dwi Novita Sari \\ Program Studi Bimbingan dan Konseling, UMN AI Washliyah Medan, Sumut, Indonesia. \\ Korespondensi: Jl. Garu II A No.93 Medan. Email: nurulazmisaragih@gmail.com
}

\author{
Article Info \\ History of Article \\ Submited July 2019 \\ Approved July 2019 \\ Published July 2019
}

\section{Key Word \\ Learning Motivation, Coping Stress, \\ Statistic}

\section{Kata Kunci}

Motivasi Belajar, Coping Stress,

Statistika

\begin{abstract}
This study aims to find out there is a stress coping relationship with the motivation to learn guidance and counseling students in statistical subjects. The data collection instrument used to measure stress coping and learning motivation is the Likert scale. Coping stress is measured based on the forms of emotional focused coping and problem focused coping, the learning motivation is measured based on the types of learning motivation which are intrinsic and extrinsic. The population of this study was guidance and counseling students and the sample of this study were 57 people. The data analysis used is Simple Correlation. The results showed that stress coping had a correlation with learning motivation with a calculated $r$ value of $0.680>r$ table 0.261 . In this analysis $r$ count is positive, the relationship between the two variables is directly proportional, namely the increase in stress coping will increase student learning motivation in statistical subjects, on the contrary the decrease in stress coping will decrease students' learning motivation in the statistics course.
\end{abstract}

\begin{abstract}
Abstrak
Penelitian ini bertujuan untuk mengetahui ada hubungan coping stress dengan motivasi belajar mahasiswa bimbingan dan konseling pada mata kuliah statistika. Instrumen pengumpulan data yang digunakan untuk mengukur coping stress dan motivasi belajar adalah skala Likert. Coping stress diukur berdasarkan bentuk-bentuk coping stress yaitu emotional focused coping dan problem focused coping, pada motivasi belajar diukur berdasarkan macam-macam motivasi belajar yaitu instrinsik dan ekstrinsik. Populasi penelitian ini adalah mahasiswa bimbingan dan konseling serta sampel penelitian ini ada 57 orang. Analisis data yang digunakan adalah Korelasi Sederhana. Hasil penelitian menunjukkan bahwa coping stress memiliki korelasi dengan motivasi belajar dengan nilai $r$ hitung sebesar $0,680>r$ tabel 0,261 . Dalam analisis ini $r$ hitung bernilai positif maka hubungan kedua variabel bersifat berbanding lurus, yakni semakin meningkatnya coping stress maka akan meningkat motivasi belajar mahasiswa pada mata kuliah statistika, sebaliknya semakin menurun coping stress maka akan menurun motivasi belajar mahasiswa pada mata kuliah statistika.
\end{abstract}

\section{Citation Info}

Saragih, N.A., dan Sari, D.N (2019). Hubungan Coping Stress Dengan Motivasi Belajar Mahasiswa Prodi BK pada Mata Kuliah Statistika. In Biblio Couns: Jurnal Kajian Konseling dan Pendidikan, 2(02), 88-95. 


\section{PENDAHULUAN}

Biblio Couns : Jurnal Kajian Konseling dan Pendidikan | Vol. 2 No. 2 Juli 2019

Kuliah merupakan suatu kewajiban mahasiswa dalam melakukan aktivitas pembelajarannya sehari-hari serta sebagai wadah bereksplorasi seluas-luasnya. Dalam memenuhi persyaratan kelulusan dari setiap semester mahasiswa wajib mengerjakan tugas yang diberikan oleh dosen dan mengikuti ujian tengah semester dan ujian akhir semester, bagi mahasiswa persyaratan tersebut bukan hal yang mudah.

Tidak sedikit mahasiswa yang berkeluh kesah, banyak faktor-faktor terjadi yang menyebabkan mahasiswa tidak dapat menyelesaikan tugas tepat waktu dan mendapatkan nilai dibawah rata-rata terkhusus pada mata kuliah statistika dalam ujian tengah semester dan ujian akhir semester, sehingga pengulangan semester yang dilakukan, hal tersebut dapat menghambat mahasiswa untuk mengerjakan skripsi sebagai salah satu persayaratan untuk mencapai gelar strata satu.

Pada umumnya perencanaan perkuliahan mahasiswa memiliki motivasi yang tinggi untuk lulus tepat waktu. Tanpa adanya motivasi dari diri sendiri tidak dapat mencapai tujuan yang diinginkan. Dalam motivasi belajar menurut Sadirman (2001, dalam Prayascitta, 2010) terdapat dua macam yaitu: motivasi intrinsik dan motivasi ekstrinsik. Motivasi intrinsik merupakan motivasi yang berasal dari dalam diri, sedangakan motivasi ekstrinsik merupakan motivasi yang berasal dari luar diri. Motivasi juga tergolong dalam beberapa komponen menurut Pintrich \& De Groot (1990, dalam Novianti, 2011) ada tiga komponen yaitu: komponen harapan, komponen nilai, dan komponen afektif.

Menurut Darsono (2000) ada beberapa faktor-faktor yang dapat mengoptimalkan motivasi belajar mahasiswa yaitu: cita-cita, kemampuan belajar, kondisi mahasiswa, kondisi lingkungan, unsur-unsur dinamis dalam belajar, upaya dosen dalam pembelajaran mahasiswa. Dikarenakan beberapa faktor tersebut tidak terpenuhi oleh mahasiswa, itu menjadi beban berat sehingga mengalami stress dan juga menyebabkan motivasi belajar mereka menjadi menurun. Banyak kejadian tersebut yang menyebabkan diantara mereka tidak melanjutkan kuliah, tidak semangat untuk belajar.

Mahasiswa bimbingan konseling banyak yang berasumsi bahwa mengambil jurusan tersebut akan mengurangi beban belajar dari ilmu matematika, kenyataannya setiap jurusan pasti akan mempelajari ilmu statistika, mahasiswa hanya mendengar mata kuliah statistika langsung merasakan tekanan batin, berpikir bagaimana dengan konsep perkuliahan tersebut, sehingga mahasiswa mengalami stress sebelum belajar mata kuliah statistika hanya dengan mendengar nama mata kuliahnya saja, dari pola pikir mahasiswa tentang mata kuliah statistika seharusnya mereka memiliki motivasi belajar yang tinggi tanpa harus berasumsi bahwa itu mata kuliah yang sulit, dan jika mereka merasa tertekan batin, dapat menggunakan strategi coping stress secara baik dan optimal untuk mengurangi stress, serta dapat meningkatkan motivasi belajar siswa secara optimal.

Berdasarkan latar belakang masalah dan pengamatan pada mahasiswa bimbingan konseling dalam perkuliahan statistika di UMN AW Medan, maka peneliti tertarik mengadakan penelitian untuk mengetahui hubungan coping stress dengan motivasi belajar mahasiswa bimbingan konseling pada mata kuliah statistika. 


\section{METODE PENELITIAN}

Desain penelitian yang digunakan dalam penelitian ini adalah pendekatan kuantitatif. Dalam penelitian ini, terdapat dua variabel penelitian yang akan diteliti yaitu variabel coping stress sebagai variabel bebas serta variabel motivasi belajar sebagai variabel terikat. Teknik yang akan digunakan dalam pengumpulan data pada penelitian ini adalah dengan skala Likert.

Dalam penelitian ini, populasinya yaitu mahasiswa bimbingan konseling semester V UMN AW Medan dan jumlah mahasiswa tersebut adalah 114 mahasiswa yang terdiri dari kelas A sebanyak 34 mahasiswa, kelas B sebanyak 47 mahasiswa dan kelas $D$ sebanyak 33 mahasiswa, yang menjadi jumlah populasi dalam penelitian ini, sedangkan sampel adalah bagian dari jumlah dan karakteristik yang dimiliki oleh populasi itu.

Metode analisis data yang digunakan pada penelitian ini adalah analisis korelasi sederhana. Sebelumnya dilakukan uji validitas dan reliabilitas skala dengan menggunakan rumus Pearson Product Moment dan Alpha Cronbach. Analisis data dilakukan dengan menggunakan bantuan program komputer SPSS 17 for windows.

\section{HASIL PENELITIAN}

Teknik analisis data yang digunakan dalam penelitian ini adalah Analisis Korelasi Sederhana dimana teknik analisis ini digunakan sesuai dengan hipotesa, yakni ingin melihat apakah ada hubungan positif antara coping stress dengan motivasi belajar mahasiswa pada mata kuliah statistika. Sebagaimana layaknya penelitian ilmiah, maka data yang akan diolah untuk pengujian hipotesis, harus melalui tahapan uji asumsi yang sesuai dengan orientasi penelitian.

\section{Uji Normalitas}

Tabel 1. Hasil Uji Normalitas menggunakan Kolmogrov-Smirnov Test One-Sample Kolmogorov-Smirnov Test

\begin{tabular}{llr}
\hline & & Unstandardized Residual \\
\hline Normal Parameters ${ }^{\mathrm{a}, \mathrm{b}}$ & & 57 \\
\hline Most Extreme Differences & Mean & .0000000 \\
\cline { 2 - 3 } & Std. Deviation & 5.78463336 \\
\cline { 2 - 3 } & Absolute & .084 \\
\cline { 2 - 3 } & Positive & .084 \\
\cline { 2 - 3 } & Negative & -.081 \\
\hline Kolmogorov-Smirnov Z & & .632 \\
\hline Asymp. Sig. (2-tailed) & & .819 \\
\hline a. Test distribution is Normal. & \\
b. Calculated from data. & &
\end{tabular}


Biblio Couns : Jurnal Kajian Konseling dan Pendidikan | Vol. 2 No. 2 Juli 2019 Dari hasil di atas, diperoleh nilai signifikansi sebesar 0,819 yang lebih besar dari 0,05 , sehingga dapat disimpulkan bahwa data dalam penelitian ini berdistribusi normal.

\section{Uji Linearitas}

Hasil analisis menunjukkan bahwa variabel bebas variabel bebas (Coping Stress) mempunyai hubungan yang linier terhadap variabel terikat (Motivasi Belajar). Sebagai kriterianya apabila $\mathrm{p}$ beda $<0,05$ maka dinyatakan mempunyai derajat hubungan yang linier.

\section{Tabel 2. Hasil Uji Linearitas}

ANOVA Table

\begin{tabular}{|c|c|c|c|c|c|c|c|}
\hline & & & $\begin{array}{l}\text { Sum of } \\
\text { Squares }\end{array}$ & $d f$ & $\begin{array}{l}\text { Mean } \\
\text { Square }\end{array}$ & $\mathrm{F}$ & Sig. \\
\hline \multirow{5}{*}{$\begin{array}{l}\text { Motivasi Belajar } \\
{ }^{*} \text { Coping Stress }\end{array}$} & \multirow{3}{*}{$\begin{array}{l}\text { Between } \\
\text { Groups }\end{array}$} & (Combined) & 2497.162 & 30 & 83.239 & 3.975 & .000 \\
\hline & & Linearity & 1405.172 & 1 & 1405.172 & 67.108 & .000 \\
\hline & & $\begin{array}{l}\text { Deviation from } \\
\text { Linearity }\end{array}$ & 1091.991 & 29 & 37.655 & 1.798 & .067 \\
\hline & \multicolumn{2}{|l|}{ Within Groups } & 544.417 & 26 & 20.939 & & \\
\hline & \multicolumn{2}{|l|}{ Total } & 3041.579 & 56 & & & \\
\hline
\end{tabular}

Dari hasil di atas, diperoleh nilai signifikansi 0,067 yang lebih besar dari 0,05. $\mathrm{Hal}$ ini berarti bahwa terdapat hubungan linier secara signifikan antara variabel coping stress dengan variabel motivasi belajar.

\section{Uji Korelasi Sederhana}

Pengujian hipotesis dalam penelitian ini dilakukan dengan menggunakan teknik korelasi sederhana dengan bantuan program SPSS 17.0 for windows. Dengan hasil data sebagai berikut:

\section{Tabel 3. Hasil Uji Korelasi Sederhana}

\begin{tabular}{llrr}
\hline & \multicolumn{2}{c}{ Correlations } & \\
\hline & & Coping Stress & \multicolumn{1}{c}{ Motivasi Belajar } \\
\hline Coping Stress & Pearson Correlation & 1 & $.680^{* *}$ \\
\cline { 2 - 4 } & Sig. (2-tailed) & .000 \\
\cline { 2 - 4 } & $\mathrm{N}$ & 57 & 57 \\
\hline Motivasi Belajar & Pearson Correlation & $.680^{* *}$ & 1 \\
\cline { 2 - 4 } & Sig. (2-tailed) & .000 & 57 \\
\cline { 2 - 4 } & $\mathrm{N}$ & 57 & \\
\end{tabular}

**. Correlation is significant at the 0.01 level (2-tailed).

Pada tabel output di atas diketahui nilai signifikansi antara coping stress dengan motivasi belajar adalah sebesar 0,000 $<0,05$, yang berarti terdapat korelasi yang signifikan antara variabel coping stress dengan motivasi belajar. Nilai Pearson 
Biblio Couns : Jurnal Kajian Konseling dan Pendidikan | Vol. 2 No. 2 Juli 2019 Correlation antara masing-masing variabel yang dihubungkan memiliki dua tanda bintang $\left({ }^{* *}\right)$, berarti terdapat korelasi antara variabel coping stress dengan motivasi belajar dengan taraf signifikansi $1 \%$. Nilai $r$ hitung untuk hubungan coping stress dengan motivasi belajar adalah sebesar 0,680 $>r$ tabel 0,261, maka dapat disimpulkan bahwa ada hubungan atau korelasi antara variabel coping stress dengan motivasi belajar.

Pearson Correlations atau $r$ hitung dalam analisis ini bernilai positif maka hubungan kedua variabel bersifat positif atau berbanding lurus, yakni semakin meningkatnya coping stress maka akan meningkat motivasi belajar mahasiswa pada mata kuliah statistika, sebaliknya semakin menurun coping stress maka akan menurun motivasi belajar mahasiswa pada mata kuliah statistika.

\section{PEMBAHASAN}

Berdasarkan hasil analisis data yang dilakukan dengan Korelasi Sederhana menunjukkan bahwa terdapat hubungan antara coping stress dengan motivasi belajar pada mata kuliah statistika dengan nilai $r$ hitung sebesar 0,680. Dalam analisis ini $r$ hitung bernilai positif yang bermakna, semakin meningkatnya coping stress maka akan meningkat motivasi belajar mahasiswa pada mata kuliah statistika, sebaliknya semakin menurun coping stress maka akan menurun motivasi belajar mahasiswa pada mata kuliah statistika. Hasil analisis tersebut sesuai dengan pendapat Darsono (2000) ada beberapa faktor yang dapat mengoptimalkan motivasi belajar mahasiswa yaitu: cita-cita, kemampuan belajar, kondisi mahasiswa, kondisi lingkungan, unsurunsur dinamis dalam belajar, upaya dosen dalam pembelajaran mahasiswa.

Secara deskriptif jelas bahwa pendapat Darsono di atas, jika mahasiswa tidak memiliki kemampuan belajar, kondisinya tidak baik, kondisi lingkungan juga kurang kondusif serta upaya dosen dalam pembelajaran kurang, maka motivasi belajar menurun, sehingga dibutuhkan cara penanganan akan kondisi tersebut yang disebut coping stress. Dengan coping stress maka mahasiswa akan senantiasa mengoptimalkan motivasi belajarnya pada mata kuliah statistika, sesuai dengan pendapat Lazarus (dalam Prayascitta, 2010) memaknai coping stress sebagai kemampuan mengubah kognitif atau perilaku secara konstan agar tuntutan-tuntutan eksternal maupun internal, khususnya yang diperkirakan membebani dan melampaui kemampuan individu dapat melemah.

Sejalan dengan pendapat Lazarus (dalam Prayascitta,2010) di atas maka peneliti memberikan asumsi sesuai hasil penelitian yang didapat yaitu $r$ hitung 0,680 dengan nilai positif, maknanya jika secara konstan mahasiswa mampu untuk melakukan coping stress ketika sedang mengikuti perkuliahan statistika maka motivasi belajar dimiliki baik itu motivasi instrinsik maupun ekstrinsik dan pastinya 
Biblio Couns : Jurnal Kajian Konseling dan Pendidikan | Vol. 2 No. 2 Juli 2019 mahasiswa mampu menerima pembelajaran dengan baik tanpa ada hambatan atau kondisi yang membebani. Dan sebaliknya, jika mahasiswa tidak mampu untuk melakukan coping stress ketika sedang mengikuti perkuliahan statistika maka motivasi belajar tidak dimiliki oleh mahasiswa dan pastinya mahasiswa tidak mampu menerima pembelajaran dengan baik. Asumsi peneliti tersebut sesuai dengan pendapat Cohen (dalam Smet, 1994) bahwa coping stress sebagai suatu proses dimana individu mencoba untuk mengelola jarak yang ada antara tuntutan-tuntutan baik itu tuntutan yang berasal dari individu maupun tuntutan yang berasal dari lingkungan dengan sumber-sumber daya yang mereka gunakan dalam menghadapi situasi stress.

Responden pada penelitian ini adalah mahasiswa bimbingan dan konseling, maka dapat terlihat bahwa mata kuliah statistika menjadi mata kuliah yang membebani mereka, sehingga peneliti sangat puas dengan hasil penelitian bahwa terdapat hubungan yang positif sehingga jika mahasiswa melakukan coping stress maka mampu memotivasi diri untuk belajar statistika, dan sebaliknya, jika tidak dapat melakukan coping stress maka tidak mampu memotivasi diri untuk belajar statistika, sesuai pendapat Sarason (1999) coping stress sebagai cara untuk menghadapi stres, yang mempengaruhi bagaimana seseorang mengidentifikasi dan mencoba untuk menyelesaikan masalah.

Hasil analisis penelitian ini menunjukkan angka korelasi sebesar 0,680, dengan nilai yang positif, pada tabel interpretasi nilai "r" product moment, nilai korelasi 0,680 dikategorikan pada interpretasi 0,60 - 0,80 yaitu antara variabel coping stress dan variabel motivasi belajar pada mata kuliah statistika terdapat korelasi yang kuat atau tinggi.

Dari data di atas diambil kesimpulan bahwa ada hubungan positif yang signifikan antara coping stress dengan motivasi belajar mahasiswa bimbingan dan konseling pada mata kuliah statistika.

\section{KESIMPULAN}

Dari hasil analisis korelasi sederhana terdapat nilai $r$ hitung untuk hubungan coping stress dengan motivasi belajar adalah sebesar 0,680 > r tabel 0,261, maka dapat disimpulkan bahwa ada hubungan atau korelasi antara variabel coping stress dengan motivasi belajar. Dalam analisis ini nilai $r$ hitung bernilai positif maka terdapat hubungan positif atau berbanding lurus, yakni semakin meningkatnya coping stress maka akan meningkat motivasi belajar mahasiswa pada mata kuliah statistika, 
Biblio Couns : Jurnal Kajian Konseling dan Pendidikan | Vol. 2 No. 2 Juli 2019 sebaliknya semakin menurun coping stress maka akan menurun motivasi belajar mahasiswa pada mata kuliah statistika.

Hasil analisis penelitian ini menunjukkan angka korelasi sebesar 0,680, dengan nilai yang positif, pada tabel interpretasi nilai " $r$ " product moment, nilai korelasi 0,680 dikategorikan pada interpretasi 0,60 - 0,80 yaitu antara variabel coping stress dan variabel motivasi belajar pada mata kuliah statistika terdapat korelasi yang kuat atau tinggi.

\section{DAFTAR PUSTAKA}

Arikunto, S, 1999. Manajemen Penelitian. Jakarta: Rineka Cipta

Arikunto, S. 2002. Prosedur Penelitian. Jakarta: Bina Aksara

Arikunto, Suharsimi. 2006. Prosedur Penelitian: Suatu Pendekatan Praktik. Jakarta: PT Rineka Cipta

Azwar, Syaifuddin. 2011. Penyusunan Skala Psikologi. Yogyakarta: Pustaka Pelajar.

Azwar, Syaifuddin. 2011. Reliabilitas dan Validitas. Yogyakarta: Pustaka Pelajar.

Bakhtiar. 2005. Penggunaan Strategi Self-Monitoring Untuk Meningkatkan Motivasi Belajar Siswa SMK. Jurnal Psiko-Edukasi. Vol 2, No 3, Hal 160-176

Dimyati, Mudjiono. 1999. Belajar dan Pembelajaran. Jakarta: Rineka Cipta.

Effendi, R, W., Tjahjono, E. 1999. Hubungan Perilaku Coping dan Dukungan Sosial Dengan Kecemasan Pada Ibu Hamil Anak Pertama. Jurnal: Anima. Vol 14, No. 54, Hal 214-228

Hawari, D. 2002. Stres, Cemas, dan Depresi. Jakarta: UI Press

Kosasih, A. 2004. Pengaruh penggunaan Media Gambar dan Motivasi Belajar Terhadap Kepribadian Siswa Pada Pendidikan Budi Pekerti. Jurnal Tabularasa. Thn II, Vol 4, Hal 40-50

Lazarus, R. S. And Folkman, S. 1984. Stress, Appraisal, And Coping. New York: Spinger Publishing Company.

Pramadi, A., Lasmono, H, K. 2003. Koping Stres Pada Etnis Bali, Jawa, dan Sunda. Jurnal: Anima. Vol 18, No 4, hal 326-340

Sardiman, A, M. 2001. Interaksi dan Motivasi Belajar Mengajar. Jakarta: PT. Raja Grafindo Persada

Sarwono. S, W. 2000. Psikologi Remaja. Jakarta: PT. Raja Grafindo Persada

Smet, B. 1994. Psikologi Kesehatan. Jakarta: Grasindo

Sudjana. 2005. Metoda Statistika. Bandung: Tarsito

Sugiyono. 2008. Metode Penelitian Pendidikan (Pendekatan Kuantitatif, Kualitatif, dan $R \& D)$. Bandung: Alfabeta 
Biblio Couns : Jurnal Kajian Konseling dan Pendidikan | Vol. 2 No. 2 Juli 2019

Tanumidjojo, Y., Basoeki, L., Yudiarso, A. 2004. Stres dan Perilaku Koping Pada Remaja Penyandang Diabetes Millitus Tipe 1. Jurnal Anima. Vol 19, no 4, Hal 399-406

Uno, H, B. 2007. Teori Motivasi dan Pengukurannya (Analisis di Bidang Pendidikan). Jakarta: Bumi Aksara.

Wlodkowski, R, J., Jaynes, J, H. 2004. Hasrat Untuk Belajar (Membantu Anak- Anak Termotivasi dan Mencintai Belajar). Yogyakarta: Pustaka Pelajar

Yusuf, Syamsu. 2009. Program Bimbingan dan Konseling di Sekolah. Bandung: Rizqi Press 